\title{
Beyond communication: using language for researching curriculum, pedagogy and policy in mathematics education
}

\begin{abstract}
The language and other media used in educational practices do not simply transmit the ideas and intentions of speakers and writers. The practices themselves shape and are shaped by what is said. The texts produced by speakers and writers in a practice such as mathematics education thus draw on ways of construing the world that are legitimate within the practice and also constrain the ways in which listeners and readers may respond.

Discourse analytic methods drawing on Halliday's systemic functional linguistics provide means of describing the world of mathematics education through analysis of its spoken and written texts. This allows us to address questions about the nature of mathematics and mathematical activity and about the nature of teaching and learning, of teachers and of students as these are produced in the texts of a given practice.

This article is based on a plenary lecture presented at the Children's Mathematical Education conference held in Poznań, Poland in July 2014. In it, I discuss a discourse analytic theoretical and methodological approach to researching mathematics education and illustrate this with examples drawn from investigations of curriculum and classroom practice.
\end{abstract}

\section{Introduction}

I shall start by elaborating the scope of my interest in communication in mathematics education. The practices of mathematics education are predomi-

Key words: communication in mathematics education, discourse, textbooks, test papers, a social semiotic approach. 
nantly discursive. That is, they take place through the use of various modes of communication and kinds of texts that share the distinctive characteristics of the practice and simultaneously function to shape what it is possible say, to do and to be. Modes of communication employed in mathematical and mathematics education practices include so-called "natural language" in written and oral modes together with a range of forms of communication that have been developed for specialised mathematical activity such as systems of mathematical notations (e.g. algebra, set notation, symbolic logic, etc.) and visual forms including specialised mathematical forms such as geometric diagrams, graphs, Venn diagrams, etc. and, more informally, the gestures that accompany faceto-face interactions. A number of researchers in mathematics education are beginning to develop approaches to analysing mathematical communication that address this multimodality (e.g. Alshwaikh, 2011; O'Halloran, 2005; Radford \& Bardini, 2007). These modes are combined in forming the texts that we study as researchers in mathematics education. These include texts that occur in classrooms: written texts such as textbooks, student exercise books, test papers; less permanent texts written on a board by teachers or students, often as part of an oral interaction; and the oral and physical interactions among teachers and students. What happens in the classroom, however, is also affected by practices outside the classroom and even outside the school. The texts produced and used in these practices include: curriculum documents; external examinations, grading schemes and reports (including those of international testing regimes such as TIMSS and PISA); policy debates and documents; reports, debates and opinion pieces in the public media; representations of mathematics and mathematicians in everyday discourse, etc. As we seek to understand mathematics education, I contend that it is relevant to subject any or all of these sources to our research analytic lens.

The usual approach to communication of research is to present the theoretical background, research questions and methodology first and then to present details of the data, analysis and findings. I intend to turn this on its head by starting with some data and analysis before addressing theoretical and methodological issues. By asking you to engage with some concrete examples, I hope to demonstrate to you that, even if you think you know nothing about it, you are already participants in discourse analysis.

In all the examples I shall look at, the basic analytical questions are essentially the same, including: 
- What is mathematics?

- What does doing mathematics involve?

- What is involved in teaching mathematics? and in learning mathematics?

- What are the characteristics of a student of mathematics?

I find that these questions enable me to address a wide range of issues, including: the nature of the intended curriculum; the potential of curricular resources to facilitate the development of valued forms of mathematical thinking and activity; the roles of teachers and students in relation to mathematical activity as anticipated in curriculum and policy documents and as seen in the classroom. See Morgan (2006) for a fuller account of the theoretical foundations of this approach.

\section{Example 1: Interrogating images in curriculum materials}

I start with an example in which communication is in pictures rather than words. Figure 1 shows the covers of mathematics textbooks for students in grades 4, 7, 10 and 12 in schools in Palestine ${ }^{1}$

First, I am sure that, even if you don't recognise the numerals used in Arabic, you can identify which book belongs to which grade. How are you able to do this? You are using your knowledge and experience as an insider in the practices of mathematics education: this is what textbooks for young children look like; this is an appropriate cover for a textbook for an advanced student. But let us be a little more analytic. What are the characteristics of these images that you are attending to and what is it that these characteristics are 'saying' about mathematics and about the students who may be the intended readers of these books?

Starting with the questions outlined above, I have identified in Table 1 some of the features of these images that function to construe the nature of mathematics and mathematical activity and of mathematics students.

\footnotetext{
${ }^{1}$ The analysis of these texts was done as part of the project "Analysing the Palestinian school mathematics textbooks: A multimodal (multisemiotic) perspective" with Dr Jehad Alshwaikh of Birzeit University. This work was supported by the British Academy International Partnership and Mobility Scheme.
} 

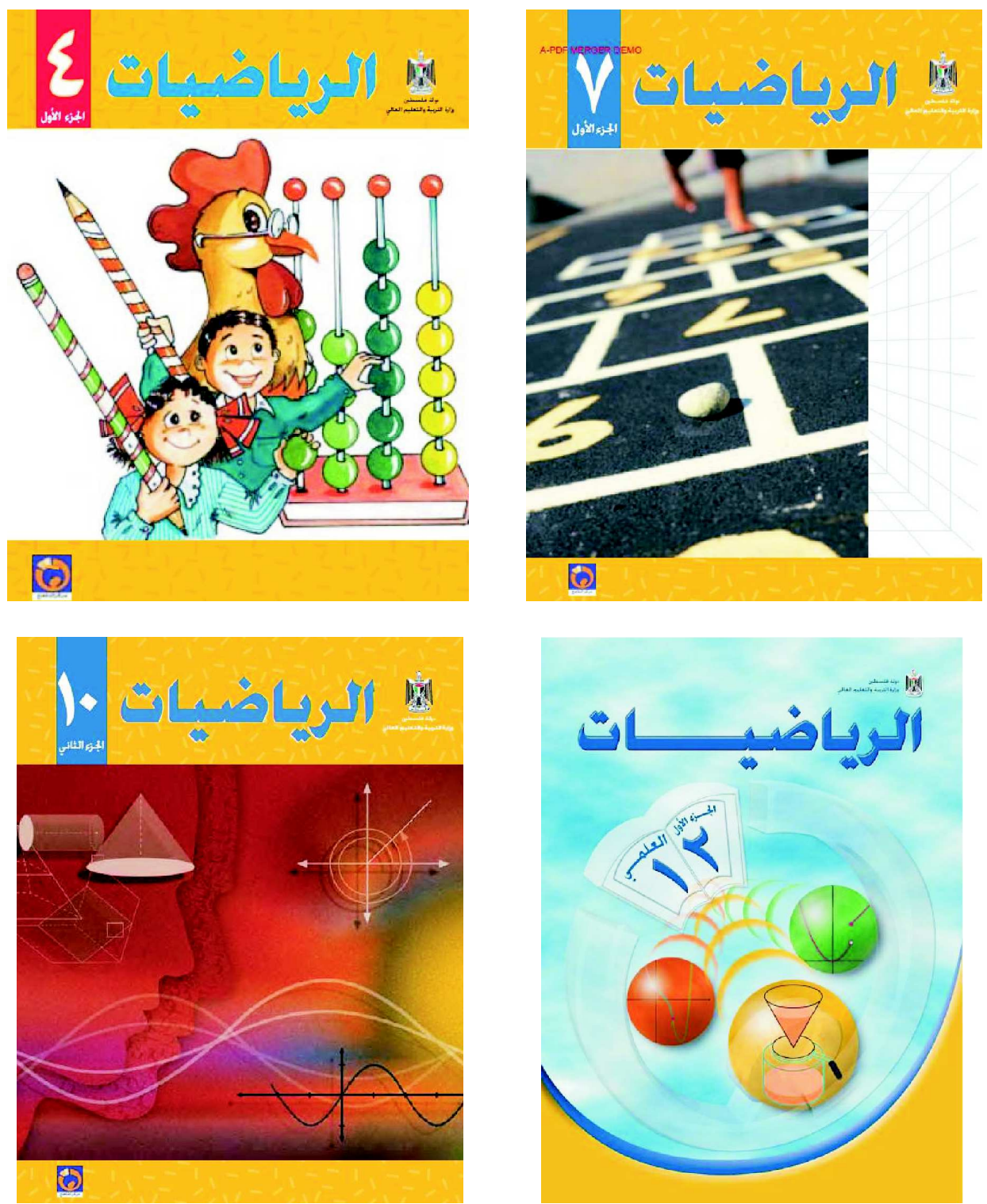

Figure 1. Textbook covers of Palestinian textbooks for grades 4, 7, 10 and 12. 


\begin{tabular}{|c|c|}
\hline Basic questions & Textual features \\
\hline What is mathematics? & $\begin{array}{l}\text { The objects represented: } \\
\text { - concrete or abstract } \\
\text { - everyday or specialised mathematical }\end{array}$ \\
\hline $\begin{array}{l}\text { What does doing ma- } \\
\text { thematics involve? }\end{array}$ & $\begin{array}{l}\text { The kinds of processes represented and the actors in } \\
\text { these processes: } \\
\text { - material or mental processes } \\
\text { - absence of active processes (i.e. displays of the } \\
\text { existence or properties of objects or relations } \\
\text { between them) } \\
\text { Human actors? Doing what? }\end{array}$ \\
\hline $\begin{array}{l}\text { What are the characte- } \\
\text { ristics of a student of } \\
\text { mathematics? }\end{array}$ & $\begin{array}{l}\text { The mode of communication: } \\
\text { - e.g. cartoon, photograph, diagram } \\
\text { Representation of affect } \\
\text { • e.g. facial expression } \\
\text { Student presence and relationship to mathematical } \\
\text { objects and processes } \\
\text { - close or distant } \\
\text { - active or passive }\end{array}$ \\
\hline
\end{tabular}

Table 1. Functional characteristics of textbook images.

I will suggest a possible reading of these images. Considering the Grade 4 book, we might say that mathematics is about manipulation of concrete objects. The cartoon style of the pictures suggests that reading this textbook might be like reading a comic book. Students doing mathematics are happy.

In Grade 7, mathematics is more explicitly about numbers, though student engagement in mathematical activity is still concrete and pleasurable, like a game.

By Grade 10, the scope of mathematics has expanded to include a wider range of concrete objects and graphical representations of abstract objects; student engagement has become more abstract and cerebral, perhaps observing and thinking about the range of specialised mathematical objects portrayed.

In Grade 12, the student is absent, except perhaps as the virtual reader of the book (recursively included in the image). Instead, mathematical objects are shown interacting with one another and with the book, construing a mathematical world in which mathematics is generated and operates independent of human activity. 
Of course it is likely that even if we (you and I and other readers) attend to the same characteristics, we may interpret them in different ways. To be confident of our interpretation of how these images might function in their context of use, we need knowledge of that context. We already share considerable knowledge of practices of mathematics and mathematics education. This common background suggests that there is likely to be a high degree of similarity in the ways we respond to these texts. However, we must be aware that there may be differences in our experiences as well as general cultural differences that affect our interpretations. In particular, any interpretation of these texts would need to take account of how the basic questions would be answered by insiders in the Palestinian education system. It is also important to note that the analysis does not imply any specific intentionality on the part of the authors or designers. While they are likely to have designed covers they consider "appropriate" to the subject matter and the age of the students, this notion of "appropriateness" is likely to be part of implicit cultural knowledge rather than the subject of explicit analytic decision-making.

\section{Some theoretical considerations: a social semiotic approach}

The functional characteristics I have identified in Table 1 are derived from the principles of the work of the linguist Michael Halliday (1985) and the development of his social semiotic approach to address multimodal forms of communication as well as verbal language (Kress \& Van Leeuwen, 2006). They are components of the lexico-grammar of the semiotic systems in use, that is, the set of elements of the system and the rules for combining these into texts that say something about the world and that play a role within some social practice.

Any text used within a mathematical social practice construes the nature of mathematics and mathematical activity through the choices made by the speakers/authors about which objects and actions to speak or write about or to portray by visual means. This constitutes an important part of the ideational metafunction of language. Halliday argues that every text (that is, every socially meaningful unit of communication - a picture, a sentence, a book, an episode of conversation, etc.) functions to construe the way in which we experience the world (Halliday, 1978). This function is realised (that is, "made real") in the lexico-grammar of the text by the transitivity system - the actors and processes (Halliday, 1985). In the context of mathematics education, I have found it relevant to enquire what kinds of objects and actions are construed 
as mathematical and to consider whether teachers and students themselves or other human participants may be agents performing mathematical actions (and what kinds of actions) or whether mathematics is construed as a system within which mathematical objects are themselves the only actors.

At the same time, every text enacts the identities of its interlocutors the author/speaker and reader/listener - the relationships between them and their relationships to the subject matter. This is what Halliday calls the interpersonal metafunction, realised in the modality of the text - expressions of judgement, probability, attitude, etc. - which in English is realised using a range of grammatical structures including adjectives, adverbs, modal adjuncts (such as may, should, will etc.). In the context of mathematics education, I have found consideration of interpersonal aspects useful for investigating pedagogic relationships, in particular identifying the evaluation criteria and the location of authority - not only authority over the behaviour of students but also mathematical authority Does the teacher have the only say about what is right or wrong or are students able to make assertions, or is authority sought within the logic of mathematical systems themselves? This metafunction also contributes to the construal of the nature of mathematical activity itself as something that may or may not involve choices and uncertainty.

\section{Example 2: Interrogating classroom activity}

I have chosen my second example from a very different source (differing in context, genre and mode of communication): two extracts from classroom transcripts. $^{2}$

Some explanation is required to set the scene. Two teachers in different schools were both working with a computer microworld, named FractionSlider, constructed using E-Slate ${ }^{3}$. The microworld provided two linked forms of representation of fraction: visually as a relationship between values shown by positions on two or more linked dynamic number lines (sliders) and, symbolically, as a rational number entered into a Logo procedure in either decimal (e.g. 0.25) or ratio (e.g. $\frac{1}{4}$ ) form. The numbers entered in the Logo procedure determined the relationships between the values displayed on the sliders. In

\footnotetext{
${ }^{2}$ These extracts were discussed from a different perspective in Morgan (2013)

${ }^{3}$ This work was undertaken by the TELMA (Technology Enhanced Learning in Mathematics) European Research Team, part of the Kaleidoscope Network of Excellence, funded by the European Community (IST-507838) under the Framework 6 Programme. See http://www.noe-kaleidoscope.org E-Slate was devised by the TELMA Athens partners (NKUA-ETL). See http://e-slate.cti.gr/
} 
the example shown here in Figure 2, as the top slider is moved, the positions of the other, dependent sliders vary in such a way as to display values, $\frac{1}{3}$ and of the value of the top slider. In Figure 2, the numerical labels have been added for the sake of clarity; when using the microworld, only the pointers are visible.

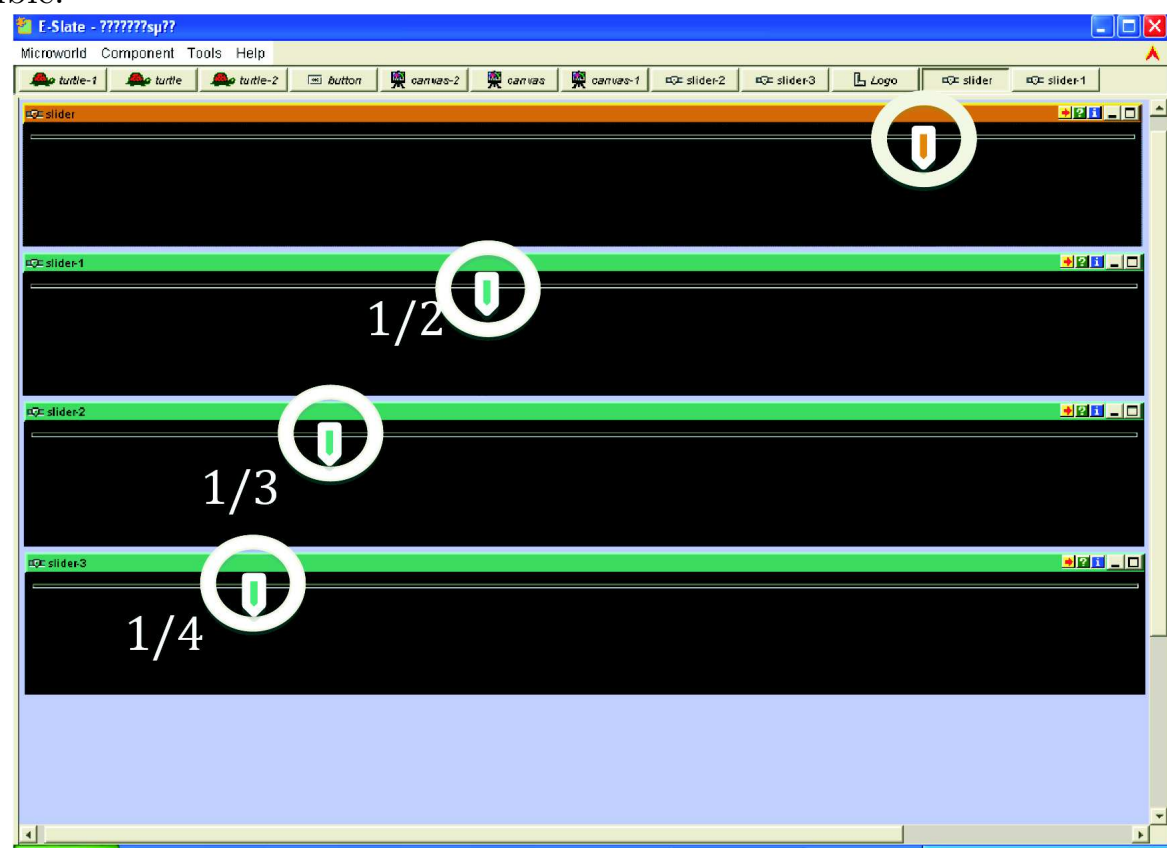

Figure 2. Fraction-Slider microworld.

The teachers had worked together to plan lessons and tasks using the microworld to engage students in comparing and ordering fractions. The two extracts in Table 2 each come from the introductory part of their first lesson. Both teachers were leading a whole class interaction, manipulating the sliders in the microworld on an interactive whiteboard. In these episodes, only a visual representation of fractions was used, similar to that shown in Figure 2; symbolic representation within the microworld was not displayed.

Again, it is easy to see differences in the mathematics and in the form of classroom interaction - which is interesting (at least to me) because the two teachers had planned together and were teaching the "same" lesson. I suspect that, unlike my first example, many readers will already have some explicit analytic tools for characterising the differences, as analysing transcripts and classrooms is a rather more common research activity in mathematics education than analysing textbook covers. 


\begin{tabular}{|c|c|}
\hline Teacher 1 (T1) & Teacher 2 (T2) \\
\hline $\begin{array}{l}\mathrm{T} 1 \ldots \text { which is the largest fraction out } \\
\text { of those two, D? [pointing to frac- }\end{array}$ & $\begin{array}{l}\text { T2 What do you think is happening here } \\
\text { when you move the top slider? [...] }\end{array}$ \\
\hline tion Slider was also displayed] & S I don't know. They just all seem to \\
\hline T1 Why do you think it might be three & one along like that in a diagonal line. \\
\hline $\begin{array}{l}\text { S Because three of the ....three sixes } \\
\ldots \text { one.... [inaudible] }\end{array}$ & $\begin{array}{l}\text { S They're moving proportionally, all } \\
\text { three of them. }\end{array}$ \\
\hline $\begin{array}{l}\text { T1 Can anybody explain a little further, } \\
\text { she's not wrong, I know she knows } \\
\text { what she's talking about. E. }\end{array}$ & $\begin{array}{l}\mathrm{T} \text { Can you try and think about what } \\
\text { those proportions might be? How } \\
\text { would you try and work it out? }\end{array}$ \\
\hline Because three [inaudible] & If you move it like that. \\
\hline T1 Right, excellent. & Move it right over to the end. \\
\hline
\end{tabular}

Table 2. Two versions of a lesson.

I address these extracts using the lens of my fundamental analytical questions. As we look at this example, I would draw your attention to the subquestions and indicators, some of which are related to those used in the previous example, though implemented this time in relation to the verbal mode rather than the visual.

The analysis pinpoints differences in the mathematics and the mathematical activity expected of the students. For the students in the class of Teacher 1, although the Fraction-Slider microworld might have afforded different kinds of objects and actions, the objects spoken of and privileged by the teacher's talk and gestures were numbers. In attempting to explain why $3 / 6$ was the larger fraction, the students also spoke of numbers. The world of mathematics in this classroom was a world of numbers and operating on numbers; the elements of the microworld were talked about only as representations of numbers. In contrast, for the students in the class of Teacher 2, the elements of the microworld and their movements were legitimate objects of mathematical analysis in their own right. The teacher endorsed the importance of the concept of proportionality when this was introduced by a student. However, when the teacher asked students to "try and work out" the proportions, this did not instigate an immediate transition to number and numerical operations: a response involving moving the objects of the microworld was also endorsed. In this classroom, the world of mathematics was not restricted to number but included a wider range of kinds of objects and relations between them. 


\begin{tabular}{|c|c|c|}
\hline Analytical questions & Teacher 1 & Teacher 2 \\
\hline $\begin{array}{l}\text { What is mathematics? } \\
\text { What are the objects? }\end{array}$ & $\begin{array}{l}\text { - fractions } \\
\text { - (objects in the mi- } \\
\text { croworld are present } \\
\text { but not spoken abo- } \\
\text { ut) }\end{array}$ & $\begin{array}{l}\text { - } \text { objects in the micro- } \\
\text { world } \\
\text { - a diagonal line } \\
\text { - proportions }\end{array}$ \\
\hline $\begin{array}{l}\text { What does doing mathe- } \\
\text { matics involve? } \\
\text { What kinds of processes } \\
\text { are represented and what } \\
\text { or who are the actors in } \\
\text { these processes? } \\
\text { Are there human actors? }\end{array}$ & $\begin{array}{l}\text { - } \text { determining pro- } \\
\text { perties of objects } \\
\text { ("which is the } \\
\text { largest") } \\
\text { - explaining reasoning } \\
\text { Students are actors. }\end{array}$ & $\begin{array}{l}\text { - movement (by ob- } \\
\text { jects in the micro- } \\
\text { world) } \\
\text { - manipulating the } \\
\text { microworld } \\
\text { - thinking } \\
\text { - trying } \\
\text { - working out } \\
\text { Students are actors but } \\
\text { so are the microworld ob- } \\
\text { jects. }\end{array}$ \\
\hline $\begin{array}{l}\text { What is involved in te- } \\
\text { aching and learning ma- } \\
\text { thematics? } \\
\text { What do teachers do? } \\
\text { What do students do? }\end{array}$ & $\begin{array}{l}\text { Teacher: asks questions; } \\
\text { evaluates responses; identi- } \\
\text { fies who may speak next; } \\
\text { follow-up questions focus } \\
\text { on extending the topic of } \\
\text { the original question. } \\
\text { Student: answers ques- } \\
\text { tions; explains their own } \\
\text { or another student's } \\
\text { answers. }\end{array}$ & $\begin{array}{l}\text { Teacher: asks questions; } \\
\text { revoices student answers; } \\
\text { identifies who may speak } \\
\text { next; follow-up questions } \\
\text { focus on new ideas intro- } \\
\text { duced by the student re- } \\
\text { sponse. } \\
\text { Student: answers qu- } \\
\text { estions; thinks about what } \\
\text { is happening; speculates. }\end{array}$ \\
\hline $\begin{array}{l}\text { What are the characteri- } \\
\text { stics of a student of mathe- } \\
\text { matics? } \\
\text { What is their relationship } \\
\text { to the teacher? } \\
\text { What is their relation- } \\
\text { ship to mathematical ob- } \\
\text { jects and processes? }\end{array}$ & $\begin{array}{l}\text { Students provide the an- } \\
\text { swers expected by the te- } \\
\text { acher. } \\
\text { Answers are valued by the } \\
\text { teacher as right or wrong. }\end{array}$ & $\begin{array}{l}\text { Students introduce their } \\
\text { own ideas. } \\
\text { Answers are valued by the } \\
\text { teacher as contributions to } \\
\text { the mathematical content } \\
\text { of the interaction } \\
\text { Uncertainty is acceptable. } \\
\text { "Trying" is acceptable. }\end{array}$ \\
\hline
\end{tabular}

Table 3. Analysis of classroom extracts.

Considering the modality of the two extracts also highlights differences in the pedagogic relationship and in particular the way that evaluation takes place. Teacher 1 placed explicit value on right answers, while Teacher 2 did not make explicit evaluative statements at all. Instead she endorsed student 
contributions implicitly by incorporating them into her follow-up questions. Whereas in Teacher 1's class students need to "know what they are talking about", in Teacher 2's class, expressing uncertainty and "trying" to think or to work out appear just as acceptable as knowing the answer. A fuller discussion of differences in the pedagogic discourse of these classrooms may be found in Morgan (2013).

\section{More theoretical considerations: a discourse the- oretical approach}

Why pay this kind of attention to the details of the communication found in classrooms and in educational texts? From a discourse theoretical perspective, language - and here I include other modes of communication - does not simply transmit the intentions of a speaker or author nor does it represent an objective reality. Rather, the ways we experience the world both shape and are shaped by language (Foucault, 1972). The forms of language used within a particular social practice not only reflect the objects, activities and values of the practice but also constrain the kinds of things that it is possible for participants to say, do and think, including differentiating between possibilities for participants with different roles. To illustrate this differentiation of possibilities, I bring to mind an episode during a conference session in which I was sharing some writing done by students, reporting on their problem solving. In one of the student texts, the student had directed his reader's attention to a pattern in his table of results: "As you can see ..." (Morgan, 1995). The response of some of the conference participants was to laugh - an indication of surprise and discomfort. While this way of addressing a reader is found frequently in textbooks, it was clearly considered inappropriate for a student to direct his reader in such an authoritative manner.

Within mathematics, our experience of the mathematical world is only in language (in which I include other modes of communication such as algebraic notation, graphs etc.). Indeed, Sfard (2008) argues that mathematical objects are entirely discursive, without any existence independent of the means by which they are communicated. Learning mathematics consists of learning to engage in mathematical discourse, using forms of mathematical communication. The ways in which students experience mathematical communication thus shape the kinds of mathematics they can engage in. 


\section{Example 3: Investigating changes in school ma- thematics}

I have argued that this approach to analysing texts provides insight into the nature of mathematics and mathematical activity and into the roles of students and teachers. I shall now illustrate how this insight can be applied to address a substantive research problem. In a recent project with Anna Sfard, we have investigated how the examinations for 16-year-olds in England have changed over the last three decades of curriculum and policy change. ${ }^{4}$ Our research problem arose in the context of national political and popular debate about "standards" of mathematics education, in particular the claim that standards have fallen over time. We see many difficulties in studying "standards", not least the fact that we have very limited access to the mathematical experience of students in the past. Examination results tell us very little as the content, questions and the ways grades are allocated also change. We therefore chose to use examination questions themselves as our lens onto the mathematics with which students have been expected to engage over the years. This choice is particularly relevant when we recognise the influence that high-stakes examinations have on students' curricular experience. ${ }^{5}$ We developed a set of analytical questions and textual indicators with which to interrogate the examinations, based on the principle that changes in the discourse - both the form of the question and of the expected student response - can be understood as changes in the mathematical activity required (see Tang, Morgan, and Sfard (2012) for an account of the development of the analytical framework) Our theoretical lens and the specific questions and indicators drew on both Halliday's social semiotics and Sfard's communicational theory as well as Sfard's characterisation of mathematical discourse.

One of the issues we looked at was the degree of specialisation of the discourse, that is, the extent to which students are expected to engage with the forms of communication that are distinctively mathematical. Among the indicators of specialisation we identified:

- specialised vocabulary (in particular the degree to which the objects and the processes present in the text are specialised mathematical objects and processes);

\footnotetext{
4 "The Evolution of School Mathematics Discourse" funded by the Economic and Social Research Council, grant reference: RES-062-23-2880

${ }^{5}$ The examination we studied was the General Certificate of Secondary Education (GCSE) examination taken by almost all students in England at the end of compulsory education (age 16). This examination is widely used as an entry qualification for further education and employment.
} 
- the use of grammatical forms that 'objectify', including nominalisation: the grammatical metaphor that changes processes (in the form of verbs) into objects (nouns);

- characteristically mathematical modes of communication, including algebraic notation, graphs, geometric diagrams etc.

It is distinctive forms of communication such as these that make mathematical activity itself distinctive. They are not just conventional (though convention certainly plays a role in their use); importantly they also provide access to engaging with mathematics itself. For example, moving from speaking/thinking about add and multiply as processes to speaking/thinking about sum and product as objects makes it possible to consider relationships between and operations upon sums and products.

Specialisation was also considered at the levels of sentence and whole questions, allowing us to consider relationships between 'pure' mathematical discourse and language arising in the context to which mathematics is being applied. The analytical framework developed in this project has allowed a quantitative analysis that shows change in levels of specialisation over time, From a high level in 1980, the first year of our sample, levels of specialisation dropped in the early 1990s, subsequently rising again, though not to the original level. This fluctuation can be related to curriculum changes introduced in 1988, emphasising the application of mathematics, and to political debates about "back to basics" in the mid-1990s, together with concern among teachers and others about the difficulty encountered by many students in reading contextualised questions. There were also at this time complaints from university mathematicians about perceived lack of skills in algebra, leading to an increase in context-free questions testing algebraic manipulation.

In order to understand what these changes mean for student engagement with mathematics, however, it is helpful to look more qualitatively at detailed examples. I shall illustrate with two questions addressing the same mathematical topic: determining the lower and upper bounds of calculations performed with measures to a given degree of accuracy. These two questions were set in examinations in 2011 (Figure 3) and 1995 (Figure 4). In both cases, a relationship is construed between mathematics and an extra-mathematical world. At the level of the whole question, therefore, both questions are concerned with application of mathematics within a non-mathematical context and thus involve the discourse of that context as well as that of mathematics. I shall attempt to disentangle this subtle relationship and to consider how mathematics itself is construed in each question. 
In the case of the question from 2011 (Figure 3), the extra-mathematical context is recognisable as the world of science or engineering: the objects "voltage", "electronic circuit" and so forth are related to each other without any reference to non-scientific objects. This is not a problem about the wiring in a building or the design of an electrical appliance. Apart from the naming of scientific objects, the question is posed using specialised mathematical language, including algebraic notation, the locution "correct to 3 significant figures" and the term "lower bound". In this question, students are expected to engage with a form of mathematics that is construed as a specialised domain, applied to a scientific context. The activity of mathematics involves operating on specialised mathematical objects: a formula, algebraic variables and "the lower bound".

貝

The voltage $V$ of an electronic circuit is given in the formula

$$
V=I R
$$

where $I$ is the current in amps

and $R$ is the resistance in ohms.

Given that $\quad V=218$ correct to 3 significant figures,

$R=12.6$ correct to 3 significant figures,

calculate the lower bound of $I$.

Figure 3. Examination question on upper/lower bounds (2011). 
Brazil has an area of $8500000 \mathrm{~km}^{2}$ correct to the nearest $100000 \mathrm{~km}^{2}$.

Write a down the limits between which the area of Brazil must lie.

$\mathrm{km}^{2}$ and

The population density of a country is the average number of people per $\mathrm{km}^{2}$ of the country.

Brazil has a population of 144 million correct to the nearest million.

(b) Calculate the maximum and minimum values of the population density of Brazil.

Maximum

Minimum

Figure 4. Examination question on upper/lower bounds (1995).

In the 1995 question (Figure 4), the domain is less clearly defined; while "population density" may be a specialised (though not pure mathematical) object, found mainly in geographic texts, the notions of area and population are much more widely encountered, for example in newspapers. Moreover, the specialised "population density" is defined in terms of the everyday phrase "number of people" and uses a grammatically complex phrase "average number of people per $\mathrm{km}^{2}$ of the country" rather than using specialised notation to express the mathematical relationship between the variables. Although the operations to be performed are similar to those required by the first question, they are not construed as highly specialised: the degree of accuracy is given using "to the nearest $100000 \mathrm{~km}^{2}$ " or "to the nearest million" rather than significant figures; the definition of population density is given in words rather 
than as a symbolic formula and all the variables are named in full rather than by single letters. The student is asked to write down the "limits" for the area of Brazil and to calculate maximum and minimum values rather than upper and lower bounds; these terms are encountered in non-specialised discourse as well as within mathematics. Thus, in this question, students are not expected to engage with mathematics as a highly specialised domain applied to another context. Instead, they are expected to engage with the context itself and to operate mathematically ("calculate") on the objects of this context. (Of course there are limits to this engagement with context. In particular, there is no rationale given in either question for performing these operations.)

In order to investigate how these differences might affect how students engage with the questions, we devised a version of the 1995 question that shared some of the more highly specialised discursive features of the 2011 question (see Figure 5). The original 1995 question and this contrived parallel version were included in tests given to a sample of 15 -year-old students from two London schools.

The population density $D$ of a country is given by the formula

$$
D=\frac{P}{A}
$$

Where $P$ is the population

and $A$ is the area in $\mathrm{km}^{2}$.

Given that, in Brazil,

$$
\begin{aligned}
& P=144 \text { million correct to the nearest million, } \\
& A=8500000 \mathrm{~km}^{2} \text { to the nearest } 100000 \mathrm{~km}^{2} .
\end{aligned}
$$

Calculate the upper and lower bounds of the population density of Brazil.

Figure 5. Contrived upper/lower bounds question, based on 1995 with 2011 features.

Students were allocated randomly to the two versions of the question, and we assume that the two groups had had a similar range of curricular experiences. There were no significant differences between overall achievement on the two versions of the test as a whole, though there were differences on individual questions. In the case of this question, both versions proved to be difficult but, while $32 \%$ of those answering the contrived (more highly specialised) version answered successfully, only $25 \%$ of those answering the original (less specialised) version succeeded in giving the maximum and minimum values of the population density. Intriguingly, the difference between success rates on the two versions was much higher in one of the schools (40\%-23\%) than in the other $(29 \%-26 \%)$; the reasons for this have yet to be investigated. 
It would be easy to say that the original version of the question was more difficult because there was too much reading to do or because students found it hard to engage with the context. These are variables that the examination boards have taken into account in more recent years as they have attempted to set questions that are accessible to a wider range of students. At the same time, however, the original question provided some structure to guide students into the problem. This might lead one to expect that it would support higher success rates - though this seems not to have been the case.

However, when we looked at the strategies that students used to attempt to find the upper and lower bounds, it is possible to suggest some other explanations of differences between the questions These strategies have been categorised in Table 4.

\begin{tabular}{|c|c|c|c|}
\hline & & $\begin{array}{l}\text { original } \\
\text { version }\end{array}$ & $\begin{array}{c}\text { contrived } \\
\text { version }\end{array}$ \\
\hline \multicolumn{2}{|c|}{ UB and LB population given } & 16 & 0 \\
\hline $\mathrm{PD}=\mathrm{P}: \mathrm{A}$ & $\begin{array}{l}\text { no UB or LB given } \\
\text { UB and LB based on result }\end{array}$ & $\begin{array}{l}1 \\
1\end{array}$ & $\begin{array}{c}5 \\
15\end{array}$ \\
\hline $\begin{array}{l}\text { UB and/or LB } \\
\text { of PD } \\
\text { calculated }\end{array}$ & $\begin{array}{ll}\text { using } P \text { and } U B \text { and } \mathrm{LB} \text { of } \mathrm{A} \\
\text { using UB and } & \mathrm{UB}(\mathrm{P}): \mathrm{LB}(\mathrm{A}) \text { and } / \text { or } \mathrm{LB}(\mathrm{P}): \mathrm{UB}(\mathrm{A}) \\
\mathrm{LB} \text { of both } \mathrm{P} & \mathrm{UB}(\mathrm{P}): \mathrm{UB}(\mathrm{A}) \text { and } / \text { or } \mathrm{LB}(\mathrm{P}): \mathrm{LB}(\mathrm{A}) \\
\text { and A } & \text { all combinations calculated }\end{array}$ & $\begin{array}{l}7 \\
4 \\
2 \\
0\end{array}$ & $\begin{array}{c}0 \\
11 \\
10 \\
1\end{array}$ \\
\hline \multicolumn{2}{|c|}{$\mathrm{UB}(\mathrm{P}): \mathrm{UB}(\mathrm{A})$ and/or $\mathrm{LB}(\mathrm{P}): \mathrm{LB}(\mathrm{A})$} & 3 & 0 \\
\hline \multicolumn{2}{|c|}{ other } & $\begin{array}{c}4 \\
38\end{array}$ & $\begin{array}{c}2 \\
44\end{array}$ \\
\hline
\end{tabular}

note: $\mathrm{UB}=$ upper bound $\mathrm{LB}=$ lower bound $\mathrm{P}=$ population; $\mathrm{A}=$ area $\mathrm{PD}=$ population density; $\mathrm{UB}(\mathrm{P})=$ upper bound of population, etc.

Table 4. Strategies for calculating upper and lower bounds.

Nearly half those answering the original version gave the upper and lower bounds of the population as their answer, making no attempt to work with the definition of population density. Perhaps the structured beginning of the problem led them to expect the need to perform the same operation on the population. This strategy was not found among those answering the contrived version, all of whom made some calculation involving both population and area. It seems likely that the provision of the formula, given in specialised notation and highlighted visually by the question layout, directed students to make some use of the formula.

Of those answering the contrived version, nearly half made the error of calculating the population density using only the given values, either giving this directly as their answer or basing a calculation of upper and lower bounds on this result. This error was anticipated as it is a common student error when 
working with bounds. However, it was barely found among those answering the original version of the question.

Half of those answering the contrived version and a third of those answering the original version made an attempt to take account of the accuracy of population and/or area in order to calculate upper and lower bounds of population density. Of these, all those answering the contrived version used upper and lower bounds of both variables - split more or less evenly between those choosing the correct combination to get their final quotients and those making the anticipated error of dividing upper bound by upper bound and lower by lower.

In contrast, we find some of those answering the original question making use of the results for upper and lower bound of area, found in the first part of the question, together with the given approximate value for population. The structured entry into the problem has not helped these students to identify the mathematical structure of the problem as a whole. Indeed it seems to have distracted them from taking account of the rest of the information provided.

Considering this analysis, it is possible to conjecture about how characteristics of the questions affect students' mathematical activity. First, the use of the specialised mathematical discourse (highlighted formula; variables named with single letters; technical vocabulary) in the contrived version seems to enable students to recognise the necessary mathematical knowledge and techniques and to identify the relevant variables. In the original version, the use of everyday language to define population density seems to have been a major stumbling block as many students failed to make use of the definition at all. Many kinds of everyday texts, unlike most specialised mathematical texts, do not demand that the reader should attend to every detail of the text in order to engage effectively. Second, the structure of the way in which the problem is posed appears to make a difference. In particular, the 'entry question' provided in the original version seems to have been a distraction rather than a support to engagement in the rest of the problem (though it did enable students to gain an easy single mark).

It is also possible that the way in which the information was structured in each question made a difference to students' recognition of the role each piece of information plays in the solution. In particular, the positioning of the definition of population density in the original version gives this little prominence. In this version, information about the area is given prominence, followed by the formula for population density and then information about population. In the contrived version, the formula is given first and highlighted, followed by equally weighted statements about area and population. This second form of presentation seems more typical of specialised discourse and may also be more 
familiar to students from their experience of mathematics textbooks.

From the point of view of those setting the examinations, the questions from 2011 and from 1995 both assessed essentially the same piece of mathematics. Both also satisfied the condition that mathematics should be applied to a non-mathematical context. The reversion to use more specialised forms of discourse appears, in this case, to enable more students to make use of specialised knowledge of the topic. On the other hand, the 1995 question with its use of everyday vocabulary, more complex grammar and non-standard knowledge structure could be argued to be a more authentic application of mathematics and to provide a test of problem solving skills. Which of these you consider the 'better' examination question depends on what aspects of mathematical activity you value more highly in the context of a high-stakes examination.

\section{Conclusion}

The examples I have given in this paper, comparing classroom episodes and examination questions demonstrate how detailed attention to the discursive characteristics of the texts used in mathematics education practices can provide insight into how those practices operate. As an approach to research, I contend that the analytical tools I have illustrated provide a powerful way for researchers to investigate a wide range of problems using textual data. Applied to curriculum, assessment and policy documents, to classroom resources, or to classroom interactions, they allow us to examine critically the assumptions about the nature of mathematics and mathematical activity that underpin the curriculum and school practices and to question the roles that are construed for teachers and learners.

Understanding how language works also has important benefits for practitioners. Analysis of two classrooms in which teachers were teaching the "same" lesson, showed how choices about how to identify the objects of interest and choices between forms of interaction can affect the nature of the mathematics encountered by students and their possibilities for engagement with that mathematics. The analysis of student answers to alternative forms of the "same" examination question showed how choices between alternative ways of saying or writing the "same" thing can make a difference to the ways in which people engage with the text and to their mathematical thinking. Awareness of the effects of such choices can empower all those involved in mathematics education to make choices that match their intentions as speakers and writers. This applies not only to the writers of examination questions or textbooks but also to teachers and students. 
At the same time linguistic awareness can enable readers to approach texts in more informed and critical ways. The notion of choices between alternative ways of speaking or writing is a key here. Asking oneself the question "how might this have been said or written differently?" opens up new possibilities for thinking and doing mathematics as well as possibilities for the critical analysis of textual data.

\section{Acknowledgements}

The textbook covers in Figure 1 are reproduced by permission of the Palestinian Curriculum Development Center, Ministry of Education.

The examination questions in Figures 3 and 4 are reproduced by permission of Edexcel Limited.

The data discussed in this article has been collected and analysed as part of collaborative projects. I would like to thank all the colleagues with whom I have worked in these projects and especially to acknowledge the contributions of Sarah Tang, Professor Anna Sfard and Dr Jehad Alshwaikh to the development of the analytical tools.

\section{References}

A $1 \mathrm{~s} \mathrm{~h} w$ a i k h, J.: 2011, Geometrical diagrams as representation and communication: A functional analytic framework, $\mathrm{PhD}$ thesis, Institute of Education, University of London. London.

F o u c a u lt, M.: 1972, The Archaeology of Knowledge (A. M. Sheridan Smith, Trans) Routledge, London.

H a 11 i d a y, M. A. K.: 1978, Language as Social Semiotic: The Social Interpretation of Language and Meaning, Edward Arnold, London.

$\mathrm{H}$ a $1 \mathrm{l}$ i d a y, M. A. K.: 1985, An Introduction to Functional Grammar, Edward Arnold, London.

K r e s s, G., V a n L e e u w e n, T.: 2006, Reading images: The grammar of visual design (2nd ed.), Routledge, London.

M orga n, C.: 1995, An Analysis of the Discourse of Written Reports of Investigative Work in GCSE Mathematics ( $\mathrm{PhD}$ dissertation), Institute of Education, University of London.

M o $\mathrm{r}$ g a n, C.: 2006, What does social semiotics have to offer mathematics education research?, Educational Studies in Mathematics, 61(1/2), 219-245.

M o r g a n, C.: 2013, Understanding practices in mathematics education: structure and text, Educational Studies in Mathematics, 128-144. 
O' H a 11 o r a n, K. L.: 2005, Mathematical Discourse: Language, symbolism and visual images, Continuum, London.

R a d f o rd, L., B a r d in i, C.: 2007, Perceiving the general: The multisemiotic dimension of students' algebraic activity, Journal for Research in Mathematics Education, 38(5), 507-530.

$\mathrm{S} \mathrm{f}$ a $\mathrm{r}$ d, A.: 2008, Thinking as Communicating: Human development, the growth of discourses, and mathematizing, Cambridge University Press, Cambridge.

$\mathrm{T}$ a $\mathrm{n} \mathrm{g}$, S., M o $\mathrm{r} \mathrm{g}$ a $\mathrm{n}, \mathrm{C} ., \mathrm{S} \mathrm{f}$ a $\mathrm{r} \mathrm{d}$, A.: 2012, Investigating the evolution of school mathematics through the lens of examinations: developing an analytical framework (Paper presented at the 12th International Congress on Mathematical Education, Topic Study Group 28 on Language and Mathematics), Seoul, Korea.

\title{
Nie tylko komunikowanie się: wykorzystanie języka do badania programów nauczania, pedagogiki i polityki w edukacji matematycznej
}

\author{
Streszczen i e
}

Badacze coraz częściej zajmują się analizowaniem w jaki sposób poprzez różnego rodzaju teksty odbywa się komunikowania się w obrębie edukacji matematycznej. Język i inne media wykorzystywane w edukacji nie tylko przekazuja idee i zamiary mówców i autorów. Teksty tworzone przez twórców w obszarze jakim jest nauczanie matematyki wyznaczają sposób interpretowania tego świata w praktyce, a także wytyczają sposób, w jaki słuchacze i czytelnicy mogą w nim funkcjonować. Każdy matematyczny tekst wykorzystany w społecznej praktyce interpretuje naturę matematyki i aktywności matematycznej poprzez wybory dokonywane przez autorów. To oni wybierają obiekty i działania, które omawiają, opisują czy przedstawiają za pomocą środków wizualnych. Stanowi to ważną część metafunkcji języka. Owe teksty to podręczniki szkolne, karty pracy, zadania egzaminacyjne, ale równie teksty pisane na tablicy przez nauczycieli i uczniów, aż po słowne interakcje między nauczycielami i uczniami.

Teoretyczne podstawy do prowadzonych analiz przedstawionych w artykule oparte są na językoznawstwie funkcjonalnym Halliday (1985). Teoria ta 
dostarcza sposobów analizowania świata matematycznej edukacji poprzez analizę tekstów mówionych i pisanych. Pozwala odpowiedzieć na pytania o naturę matematyki i aktywności matematycznej oraz określić charakter nauczania i uczenia się, roli nauczycieli i uczniów, tak jak są one ukierunkowane poprzez teksty. Halliday twierdzi, że każdy tekst (czyli każda jednostka mająca znaczenie w społecznej komunikacji - rysunek, zdanie, książka, fragment rozmowy, itd.) posiada funkcję budowania sposobu, w jaki doświadczamy świata (Halliday, 1978). W kontekście matematycznej edukacji istotne jest analizowanie jakie obiekty i działania są rozumiane jako matematyczne. Warto się zastanowić się, czy nauczyciele, uczniowie lub jeszcze inni uczestnicy mogą być aktorami realizującymi aktywności matematyczne (jeżeli tak, to jakiego rodzaju są to działania). Być może jest przeciwnie - matematyka jest rozumiana jako system, w którym jedynymi aktorami są obiekty matematyczne.

Równolegle z każdym tekstem współistnieją tożsamości dwóch interlokutorów: strony nadającej oraz odbierającej, co stwarza relacje między nimi i pociąga za sobą relację do przedmiotu, którego tyczy tekst. Jest to to, co Halliday nazywa metafunkcją interpersonalną, realizowaną poprzez sposób, w jaki tekst jest zbudowany - wypowiedzi oceniające, prawdopodobne, wyrażające postawę w stosunku do treści, itp. W kontekście nauczania matematyki uwzględnienie aspektów interpersonalnych jest przydatne przy badaniu pedagogicznych relacji, w szczególności przy identyfikowaniu kryteriów oceny i lokalizacji autorytetów - nie tylko w odniesieniu do zachowań uczniów, ale również przy ustaleniu autorytetów matematycznych. Czy to nauczyciel ma decydować, co jest dobre a co złe? A może to uczniowie są w stanie wyrażać swoje przekonania? Albo poszukiwanie autorytetu powinno odbywać się w samej logice matematycznego systemu? Ta metafunkcja przyczynia się również do interpretacji samej działalności matematycznej jako czegoś, co może dotyczyć wyborów i niepewności.

W artykule zostały przedstawione analizy trzech przykładów. Pierwszy polega na próbie odczytania charakteru matematyki zawartej w podręczniku (oraz oczekiwań w stosunku do uczniów) poprzez interpretację rysunków na okładkach. Przykład drugi pokazuje analizę fragmentu jednej lekcjach prowadzonej przez dwóch różnych nauczycieli z wykorzystaniem tej samej pomocy dydaktycznej. Ostatni przykład analizuje, w jaki sposób sformułowanie zadania egzaminacyjnego może wpływać na odbiór tego zadania przez uczniów, a w rezultacie na sposób pracy nad tym zadaniem i osiągane wyniki.

Pytania oraz ich specyfikację, stawiane w odniesieniu do pierwszego przykładu, można zestawić w tabeli. Sposób stawiania pytań jest wzorowany na propozycjach teoretycznych M. Halliday. 


\begin{tabular}{|c|c|}
\hline Pytania podstawowe & Cechy tekstu \\
\hline $\begin{array}{l}\text { Czym jest matematy- } \\
\text { ka? }\end{array}$ & $\begin{array}{l}\text { Obiekty, które reprezentuje: } \\
\text { - konkretne czy abstrakcjne, } \\
\text { - codzienne czy specjalistyczne matematyczne. }\end{array}$ \\
\hline $\begin{array}{l}\text { Co składa się na upra- } \\
\text { wianie matematyki? }\end{array}$ & $\begin{array}{l}\text { Rodzaje reprezentowanych procesów oraz uczestnicy tych } \\
\text { procesów: } \\
\text { - procesy materialne lub mentalne, } \\
\text { - brak aktywnych procesów (np. prezentowanie ist- } \\
\text { nienia własności lub relacji pomiędzy nimi). } \\
\text { Czynnik ludzki? Jego rola? }\end{array}$ \\
\hline $\begin{array}{l}\text { Jaka jest charakterysty- } \\
\text { ka ucznia uczącego się } \\
\text { matematyki? }\end{array}$ & $\begin{array}{l}\text { Sposoby komunikowania się z uczniem: } \\
\text { • np. postaci z kreskówek, fotografie, diagramy. } \\
\text { Reprezentowanie uczuć } \\
\text { • np. wyraz tworzy. } \\
\text { Współuczestniczenie i relacje w odniesieniu do obiektów i } \\
\text { procesów matematycznych } \\
\text { • bliskie czy na odległość } \\
\quad \text { - aktywne lub pasywne. }\end{array}$ \\
\hline
\end{tabular}

Analiza drugiego przykładu pokazała różnice w obrazie matematyki, aktywności matematycznych oczekiwanych od uczniów oraz $\mathrm{w}$ formie interakcji w dwóch równoległych klasach. W jednej z klas świat matematyki dotyczył liczb i umiejętności operowania nimi. W klasie drugiej elementy mikroświata (pomocy w formie suwaka ułamkowego) były uzasadnione przedmiotem analizy związków matematycznych samych w sobie. W tej klasie świat matematyki nie był ograniczony do liczb, ale obejmował szerszy zakres rodzajów obiektów i relacji między nimi.

Przykład trzeci jest wynikiem szerszego projektu badawczego, w ramach którego badano jak w ciągu ostatnich trzech dekad zmieniły się egzaminy dla 16-latków w Anglii. Odbywało się to w kontekście dyskusji nad „standardami” nauczania oraz spadku poziomu kompetencji uczniów. Wychodząc z założenia, że zmiany w dyskursie - zarówno w formie pytań i oczekiwanej odpowiedzi uczniów - moga być rozumiane jako zmiany w wymaganej aktywności matematycznej, zostały poddane analizie sposoby redagowania treści zadań egzaminacyjnych. Wśród wskaźników specjalizacji znalazły się: 
- specjalistyczne słownictwo (w szczególności stopień, w jakim cele i procesy występujące w tekście są wyrażone poprzez obiekty i procesy matematyczne);

- stosowanie form gramatycznych wpływających na obiektywizowanie, w tym nominalizacji: metafory gramatycznej, która zmienia procesy (w formie czasownika) na obiekty (rzeczowniki);

- występowanie trybów charakterystycznych w matematycznej komunikacji, w tym notacji algebraicznej, wykresów, diagramów, geometrycznych rysunków itp.

Przykłady podane w tym artykule pokazują, jak szczegółowa analiza dyskursywnych cech tekstów stosowanych w praktyce edukacyjnej matematyki może dostarczyć wglądu w mechanizm działania tej praktyki. 